\title{
The Correlation of Food and Physical Activity with Diabetes Incidence Among Older-Adult
}

\author{
Indonesian Nursing Journal of Education and \\ Clinic (INJEC) \\ |66-17| \\ Volume 5, Issue 2, December 2020 \\ DOI: 10.24990/injec.v5i2.286 \\ injec.aipni-ainec.org/index.php/INJEC/index \\ Received : 2020-05-10 \\ Accepted : 2020-09-0I \\ The Association of Indonesian Nurse \\ Education Center (AINEC)
}

\author{
Maria Getrida Simon' ${ }^{\prime}$, Sakti Oktaria Batubara ${ }^{2} \mathbb{D}$
}

\begin{abstract}
Introduction: Diabetes in older adults is associated with higher mortality, reduced functional status, and increased risk of institutionalization. Older adult with Diabetes type 2 additionally have high risk for both intense and constant microvascular and cardiovascular disease. The purpose of this study is to analyze the correlation of food and physical activity with diabetes incidence among older adults in Pasir Panjang public health community, Kupang.

Methods: The research used observational analytic design with cross-sectional approach. The sampling technique taken was convenience sampling. The samples were 120 respondents. To analyze food and physical activity with DM incidence, the researchers used a statistical chi square. To measure activity, the instrument used was the Global Physical Activity Questionnaire (GPAQ) from the WHO and to measure food it used the Indonesian Family Life Survey (IFLS) from Indonesia's health ministry. Results: This study showed that there was a correlation between food and type 2 DM incidence for the older adults in Pasir Panjang public health community Kupang $(p=0.008<0.05)$, but there was no correlation between activity with the incidence of type $2 \mathrm{DM}(p=0.138>0.05)$.

Conclusion: Nurses need to create suitable health education regarding food consumed for older adult with type 2 diabetes, and involve their family to support patients to consume the diet.
\end{abstract}

\section{Keywords}

food; older adult; physical activity; type 2 diabetes mellitus

\section{INTRODUCTION}

The development of science and technology in today's world is increasingly sophisticated, but it does not always bring positive impacts on people's lives. Some developments specifically change a person's lifestyle, mindset and habits. Lifestyle relates to consuming fast food habitually, which is dangerous to body health, obesity, and lack of physical activity. All this causes a person to suffer from type 2 diabetes mellitus (DM) (Fatimah, 20I5). DM is a health problem that affects productivity and decreases the quality of human resources. Statistics from the International Diabetes Federation (Federation, 2019) state that, today, approximately 463 million people worldwide suffer from the disease. This number continues to grow up to $3 \%$ or about seven million people every year.

\footnotetext{
I Universitas Katolik Santu paulus Ruteng, Nusa Tenggara Timur, Indonesia

2 Univesitas Citra Bangsa
}

Corresponding Author:

Maria Getrida Simon, Unika Santu paulus Ruteng, Nusa Tenggara Timur, Indonesia

Jl. Ahmad Yani 10 Manggarai NTT Tenda, Watu, Ruteng, Kabupaten Manggarai, Nusa Tenggara Timur Postcode: 865 I I

Email: riasimon0307@gmail.com 
The finding may reach 350 million by 2025 and half of them are located in Asia, especially India, China and Indonesia (Tandra, 2008). According to data from the Indonesian Ministry of Health, two-thirds of diabetics do not know they have been infected.

The cost of treatment needed by the Indonesian government to solve the problem above reaches to Rp. 500 billion per year. As such, people need to know the risk factors. Group of people at risk by type 2 DM are older adults ( $<45$ years). According to the Indonesian Ministry of Health, (2018), the older adults age is in the range of 36-45 years, where they are hoped to be the next generation of the nation. When these young people have been infected by the degenerative disease, their life expectancy for the next 20 years and the quality of Indonesia's demographic bonus will be influenced.

DM is a disease concerned by Health Workers in East Nusa Tenggara Province (NTT). Based on 2018 Basic Health Research (Kemenkes RI, 2013) data, $0.9 \%$ of people suffered from DM for up to 15 years in NTT. In 2017, based on Kupang Department of Health (Kemenkes RI, 20I7) data, Pasir Panjang public health community has the highest prevalence among the many health centers in Kupang City, the second is Kupang Kota public health community and the third rank is Penfui public health community (Naimasus, 2015). Medical records data in Pasir Panjang public health community showed that, visit rate of DM patients in 2016 amounted to 125 times and, in 2018, in the last three months, as many as 200 times. Research from Dewi (2019) on the analysis of factors affecting type 2 diabetes mellitus incidence showed physical activity and food have a significant relationship with the incidence of type 2 diabetes mellitus.

Many factors affect the disease. By knowing its causes, we can detect and prevent it, especially for the older adults, to increase Indonesia's life expectancy for the next 10 years in accordance with the government's program on the Healthy Community Movement. Based on the description above, the research team was interested in examining the effect of age and family history on the incidence of diabetes mellitus in public health community. The purpose of this study is to analyze the correlation of food and physical activity with diabetes incidence among older adults in Pasir Panjang public health center, Kupang.

\section{MATERIALS AND METHODS}

The study used observational analytical design with cross-sectional approach, which emphasizes the measurement time and observation of food and physical activity (independent variable) and diabetes incidence (dependent variable) (Nursalam, 2016).

The total population was 130 respondents. Sample was obtained by convenience sample technique, which means that, after the participants signed the consent letter, the researchers selected samples according to the determined inclusion criteria. The subjects in this study were all DM young adult patients, with the following inclusion criteria: I) The age of respondents was between 36-45 years old, 2) stayed around public health center Pasir Panjang, 3) Not infected by other diseases, 4) willing to be a respondent. Based on the criteria, the respondents suitable to this research totaled 120, 10 respondents declined to participate.

Data collection was done from March 20th to May 18th, 2019 located at Pasir Panjang public health community, Kupang City, East Nusa Tenggara Province (Nusa Tenggara Timur/NTT). The instruments used in this research are standard Questionnaire and Global Physical Activity Questionnaire (GPAQ) taken from the WHO. The instrument of physical activity consists of five questions in which each question has four answer choices, namely routine, frequent, sometimes and never. The categories for activities are not active $(>10)$ and active (1020). To measure the food factor, researchers used the Indonesian Family Live Survey (IFLS) from the Indonesian Health Ministry in which there are six questions in which each question has four choices: never, sometimes, always and routinely. Food factors are categorized into two, namely risk food consumption (12-24) and non-risk food consumption $(<12)$. 
This study has considered ethics such as informed consent, anonymity and mutual confidentiality and has obtained permission from the head of Kupang City Health Office. After obtaining approval, the researchers conducted a study by going to the outpatient clinic every day to meet with respondents according to established inclusion criteria. After explaining the purpose and objectives of the study to the respondent, the researchers

Table I. Characteristics of respondents $(n=120)$ accompanied the respondent to fill out the questionnaire and explain if there was something that was not understood by the respondent.

All data collected have been analyzed using Statistical Product and Service Solutions (SPSS) 16. Then the researchers analyzed the factors of food and activity on the incidence of DM with chi square correlation statistical test where it measured the correlation between

\begin{tabular}{lll}
\hline Variable & $\mathbf{N}$ & $\mathbf{\%}$ \\
\hline Age & & \\
$35-40$ & 56 & 46.6 \\
$41-46$ & 64 & 53.4 \\
Sex & & 45.8 \\
Men & 55 & 54.2 \\
Women & 65 & \\
Education & & 4.2 \\
Elementary school & 5 & 10.0 \\
Junior high school & 12 & 46.7 \\
High school & 56 & 39.2 \\
College & 47 & 34.2 \\
Employment & & 5.8 \\
Public Servants & 41 & 6.7 \\
Military/Police & 7 & 5.0 \\
Farmer & 8 & 30.8 \\
Laborer & 6 & 17.5 \\
Entrepreneur & 67 & 58.3 \\
No-job & 37.7 \\
YM History & 21 & 41.3 \\
No & & \\
\hline
\end{tabular}

Table 2. Distribution of respondents based on food consumed and physical activity by DM patients in Pasir Panjang public health community

\begin{tabular}{lcc}
\hline Variable & $\mathrm{n}$ & $\%$ \\
\hline Food consumed & & \\
Risk & 61 & 50.8 \\
No-risk & 59 & 49.2 \\
Physical activity & & \\
Active & 66 & 55.9 \\
Not-active & 54 & 44.1 \\
\hline
\end{tabular}

Table 3. Effect of food on DM incidence in Pasir Panjang public health community

\begin{tabular}{llllll}
\hline \multicolumn{1}{c}{ DM history } & \multicolumn{2}{c}{ Food consumed } & Total & P value \\
\hline yes & & Risk & No-risk & & 0.008 \\
Not & 35 & & 27 & 62 & \\
Total & 26 & 32 & 58 & \\
\hline
\end{tabular}

Table 4. Effect of food on DM incidence in Pasir Panjang public health community

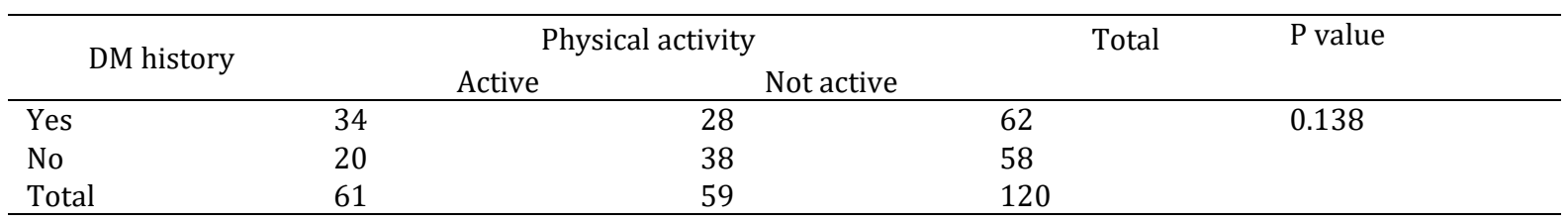


two variables (Nursalam, 20I6). This study was approved by ethical statement number ERB. N0. 52/EC/20I9 from Citra Husada Mandiri ethical review board.

\section{RESULTS}

\section{Univariate Results}

The total respondents were 120 people. The characteristics of respondents' data are presented in Table I. Based on Table I, the majority age in this study is in the range of $4 \mathrm{I}$ $46(53.4 \%)$, the number of women is more dominant (54\%) than men (45.8\%). The majority of respondents, as many as 56 people (46.7\%), had a high school education and the majority of respondents, 4 I people (34.2\%), were working as public servants. From DM history it showed that most respondents had DM history (58.3\%).

Table 2 showed that the most respondents, $6 \mathrm{I}(50.8 \%)$, consumed foods that were at risk and showed that most respondents, or 66 people (55.9\%), were not physically active.

\section{Bivariate Results}

Chi square test results indicate $P$ value $0.008<0.05$, so that it can be concluded that there is a correlation between food and the incidence of diabetes mellitus. In Table 4, chi square analysis shows $p$ value $0.138>0.05$, so there is a significant correlation between physical activity and the incidence of diabetes mellitus.

\section{DISCUSSIONS}

\section{Effect of Food Factors on the Incidence of $D M$}

Chi square results showed $P$ value $0.008<0.05$, so there is a correlation between food and the incidence of diabetes mellitus. In this study, it was found that most respondents, or $6 \mathrm{I}$ people $(50.8 \%)$, consume dangerous food (sweet food) and 59 respondents (49.2\%) always consume harmless food.

Diabetes mellitus (DM) is known by the public as diabetes or a chronic disease characterized by increased blood sugar levels as a result of the disruption of the metabolic system in the body. This can be caused by the failure of pancreatic organs to produce the hormone insulin as needed (Suiraoka, 20I2). DM sufferers are still allowed to eat like normal people, but they must be able to control themselves in terms of eating schedules, the amount and type of food consumed (Sudarmingsih, 2006). According to Dewi (2013), good diet should be understood by DM patients. In addition, the type of food also needs to be considered because it can determine the speed of increase in blood sugar levels. Food compositions for people with diabetes should include carbohydrates, fats, proteins, fruits and vegetables. DM sufferers usually tend to have uncontrolled sugar content (Susanto, 20I3). This habit also can be a result of ease of access to fast food ( $\mathrm{C}$ and G, 2009). Especially as, in Indonesia, it is easy to find noodles, canned food and any other fast food. Based on the respondents' answers, the majority of them always consume sweet food about twice a day, drink sweet tea and frequently eat fast food.

This study is in line with research conducted by Susanti (2018) that there is a correlation between diet and blood sugar levels of people with DM. The respondents chosen in this study were older adults as those of productive age often consume foods that contain lots of carbohydrates and sugar. Blood sugar levels will increase dramatically after consuming foods that contain lots of carbohydrates and / or sugar (Nurrahmani, 2012). The results of this study also showed that the majority of respondents (58.3\%) have had family history of DM. Such patients can increase the incidence of DM, especially supported by uncontrolled dietary habits. The results also showed that $54.2 \%$ of respondents were women. Women consume more sweet foods, such as chocolate, sugar and fast snacks, than men. Therefore, DM sufferers need to maintain a diet and type of food so that blood sugar remains controlled. One of the questions in the questionnaire concerned consuming sugar food like chocolate, candy and cookies and $40 \%$ of respondents answered they routinely consumes and $20 \%$ of respondents answered always consumed sweet food.

\section{Effect of Activity Factors on the Incidence of DM}


Chi square results indicates $P$ value $0.138>0.05$, so it can be concluded that there is no correlation between physical activity and the incidence of diabetes mellitus. The results showed that some respondents, or 66 people (55.9\%), were physically active, while some respondents, or 54 people (45.1\%), were not physically active. Physical activity is generally interpreted as gestures caused by skeletal muscles and resulting in energy expenditure. Physical activity is a form of behavior, while energy expenditure is the result of that behavior (Breen, Gibney and O'Shea, 20I5). In doing physical activity, the muscles use the glucose that is stored so that the stored glucose will be reduced. Research conducted by Barnes (20I2) stated that physical activity is directly related to the speed of muscle blood sugar recovery.

Another study from Ranasinghe (2015) showed that physical activity is proven to help prevent and control diabetes, both independently, and through weight control. Most participants in Ranasinghe were aware about the importance of being physically active but they had lack of consensus and clarity with regards to type, duration, timing and frequency of physical activity.

This research is supported by research conducted by Hariyanto (2013) in which there is no correlation between physical activity and the incidence of diabetes mellitus. This is supported by Abidah (20I6), who stated that there is no correlation between physical activity habits with the incidence of diabetes mellitus. According to research, physical activity like daily activity (cleaning house) is not correlated with DM because although the activity burns calories, fewer calories burn than in a sport. In the questionnaire, this question had $70 \%$ of respondents answer saying that they thought it was enough to burn calories. However, this study is different from that conducted by Kaunang, (2018) which stated that there is a significant correlation between physical activity and the incidence of diabetes in outpatients at Interna policlinic RSUD Bitung.

The insignificant correlation between independent variable and blood glucose levels in patients with DM may be caused by a small number of respondents or other factors such as risk factors for DM disease, as it is known that physical activity is not the only factor influencing the incidence of diabetes mellitus. The results also showed that $54.2 \%$ of respondents were women; in general, women still did household chores and the energy to do so could burn glucose in the body.

\section{CONCLUSION}

Based on research, there are still many DM patients in late adulthood who still consume many foods that increase blood sugar and assume that simple activities such as cleaning the house can help to lower blood sugar so that it does not require additional exercise. Nurses need to create suitable health education regarding food consumed by older adult with type 2diabetes, and involve their family to support patients to consume the diet. For further research, it is recommended doing longitudinal study to see the effect of diet in DM 2. From the above research findings, it can be suggested that early prevention is very important for patients with type 2 DM for older adults.

\section{Acknowledgement}

Thanks to all humble people at Pasir Panjang public health community for agreeing to be interviewed and giving us all needed data. We also thank the academic community of Unika Santu Paulus Ruteng and Universitas Citra Bangsa for the circumstances we were provided for this research to be a success.

\section{Conflict of Interest}

All the authors have no conflict of interest related to the study.

\section{REFERENCES}

Abidah, N. 2016. "Kebiasaaan Aktivitas Fisik Pasien Diabetes Melitus Terhadap Kadar Gula Darah Di Rumah Sakit Umum Dr. Fauziah Bireuen."

Breen, C, MJ Ryan M Gibney, and D O'Shea. 2015. "Diabetes-Related Nutriton Knowledge and Dietary Intake among Adults with Type 2 Diabetes." British journal nutrition.

C, Morgan, and Hutchinson G. 2009. The Social Determinants of Psychosis in Migrant and 
Ethnic Minoritary Populations. a public health tragedy. psychol med.

Dewi. 2013. Menu Sehat 30 Hari Untuk Mencegah Dan Mengatasi Diabetes. Jakarta: Media Pustaka.

Fatimah, Restyana Noor. 2015. Diabetes Melitus Tipe 2. Lampung: Medical faculty, Lampung University.

Federation, international diabetes. 2019. "IDF Diabetes Atlas 9th Edition." https://www.diabetesatlas.org/en/.

Hariyanto, F. 2013. "Hubungan Aktifitas Fisik Dengan Kadar Gula Darah Puasa Pada Pasien Diabetes Melitus Tipe 2 Di Rumah Sakit Umum Daerah Kota Cilegon." Ejournal syarif hidayahtullah 2.

Kaunang, Wulan PJ, Fima LFG Langi, and Fakultas Kesehatan Masyarakat Universitas Sam Ratulangi Manado ABSTRAK. 2018. "Hubungan Aktivitas Fisik Dengan Kejadian Diabetes Melitus Pada Pasien Rawat Jalan Di Rumah Sakit Umum Daerah Kota Bitung." Jurnal KESMAS 7(5).

Kemenkes RI. 2013. Riset Kesehatan Dasar. Jakarta.
2017. "Profil Kesehatan NTT Tahun 2017." Kementrian Kesehatan Republik Indonesia: 40.

Naimasus, Ridwan Stenly. 2015. "Hubungan Dukungan Keluarga Dengan Motivasi Pasien Diabetes Melitus Dalam Mengontrol Gula Darah Di Wilayah Kerja Puskesmas Pasir Panjang."

Nurrahmani. 2012. Stop! Diabetes. Yogyakarta: Araska.

Nursalam. 2016. Metodologi Penelitian IImu Keperawatan. Jakarta: Salemba medik.

Ranasighe, P. Pigera, A. S. A. D, M.H Ishara, L. M. D. T Jayasekara, and P. Jayawardena, $R$. katulanda. 2015. "Knowledge \& Perception about Diet and Physical Activity among Sri Lanka Adults with DM: A Qualitative Study." BMC public health.

Sudarmingsih. 2006. "Pola Makan Dan Kejadian Sindroma Metabolik.” In Temu Ilmiah Asdie, Semarang.

Suiraoka. 20I2. Penyakit Degeneratif. Yogyakarta: Nuha medika.

Susanto, T. 2013. Diabetes, Deteksi, Pencegahan, Pengobatan. Jakarta: Buku pintar.

Tandra, H. 2008. Segala Sesuatu Yang Harus Anda Ketahui Tentang Diabetes. Jakarta: Gramedia pustaka utama. 